\title{
Folklore in the Debates of the Westernizers and Slavophiles
}

\author{
Linda Ivanits \\ Russian and Comparative Literature \\ Penn State University \\ University Park, PA \\ USA
}

\begin{abstract}
\end{abstract}
Russian folklore played an important role in the debates of the Slavophiles and Westernizers about national identity. Some Slavophiles adduced folksongs as evidence of the essential Christianity of the Russian people, while Westernizers, in good part, viewed folklore as a primitive stage in the development of a national literature that reflected the oppression and dejection of the masses. English-language studies of the Slavophile-Westernizer controversy contain at best passing mention of folklore. My essay hopes to partially remedy this situation by offering an overview of the role of folklore in the skirmishes between the early Slavophiles and Westernizers.

In his History of Russian Ethnography (1891, История русской этнографии), A.N. Pypin sketched a bleak picture of the status of Russian folklore during the reign of Nicholas I. Attempts at interpretation were often naïve or misguided, and the most widely acclaimed collection of the time, I.P. Sakharov's Tales of the Russian People (1841, Сказания русского народа), was subsequently discredited for erroneous information, unaccredited borrowing, and falsification. Harsh, erratic censorship, which tended to prohibit songs about bandits and peasant discontent, impeded publication of valuable collections, most notably that of P.V. Kireevskii [Pypin 1891: vol. 1, 376-89]. (1) Even so Slavophiles, Westernizers, and adherents of the "official" nationality promulgated by the regime energetically gathered and compiled folklore. Their materials served as the basis for many of the monumental collections published in the reign of Alexander II, including those of A.N. Afanas'ev [1858, 1859], P.V. Kireevskii [186074], P.A. Bessonov [1861] and V.I. Dal' [1861, 1863, 1880.] In the 1830 s and 1840s the word "narodnost" was so fashionable that V.G. Belinskii called it the "alpha and omega of the aesthetics of our time" and rightly noted its lack of fixed definition [1955: vol. 5, 289]. Coined 
by Prince P.A. Viazemskii, the term first expressed the aspiration of the Russian Romantics of the 1820 s to create a national literature on par with the great literatures of Western Europe [Leighton 1987 viii-ix]. By the late 1830 s and 1840 s the term was closely intertwined with the debate about Russian distinctiveness and world significance, which had now reached an acute stage and would set parameters for discussing national identity thereafter [See Chizhevskii 1939: 32]. Both Slavophiles and Westernizers adduced folklore in support of their positions and, while many of their contentions seem jejune from today's perspective, Russian scholarship has always acknowledged the important role they played in the debate. English-language studies of the Slavophile-Westernizer dispute contain at best passing mention of folklore. (2) My essay hopes to partially remedy this situation by offering an overview of the role of folklore in the skirmishes between the early Slavophiles and Westernizers.

Though Russian folklore as a discipline was in its infancy in the reign of Nicholas I, a significant amount of material was in print and it stretched across multiple genres, including epics, historical songs, folktales, calendar songs, wedding songs, and lyrics (precise genre specifications were yet to be determined). Kirsha Danilov's Ancient Russian Songs (Древние российские стихотворения, собранные Киршею Даниловым) had been reprinted in 1818 and M.A. Maksimovich's collection of Ukrainian folksongs (Малороссийские песни) appeared in 1827. Not surprisingly, adherents of official nationality were fairly successful in getting their material by the censors and published several important Russian collections, including I.M. Snegirev's Russian Celebrations and Superstitious Rituals of the Simple Folk (Русские [Руские] простонародные праздники и суеверные обряды, 1837), Sakharov's Tales of the Russian People, and A.V. Tereshchenko's Daily Life of the Russian People (Быт русского народа, 1848). (3) The leading journals of the day, including the western-leaning Notes of the Fatherland (Отечественные записки) and Contemporary (Современник) and especially M.P. Pogodin's conservative monthly The Muscovite (Москвитянин) included a good deal of folklore on their pages as well as reviews of folklore collections. Though not technically a Slavophile journal except for the three months in 1845 when Ivan Kireevskii took over the editorship, The Muscovite was generally hospitable to the Slavophiles. In addition, literary reworkings and imitations of folklore were in vogue and so widespread that it was often impossible to distinguish between them and actual folk 
texts [Skaftymov 1936: 139]. In any case, at this time folklore and literature were generally not thought of as separate entities.

Perhaps the most prolonged and expansive effort at collecting folksongs of all types during the reign of Nicholas I was that of Petr Vasil'evich Kireevskii. (4) One of the more curious figures in the history of folkloristics, Petr Kireevskii nurtured a love of native traditions and Orthodoxy as well as an aversion to the reforms of Peter the Great well before the Slavophile-Westernizer controversy acquired clear lines of division [Brodskii 1910: 22-23; Walicki 1975: 122-23]. His work stretched over a quarter of a century, involved over eighty correspondents, among them A.S. Pushkin, N.M. Iazykov and his family, K.D. Kavelin, N.V. Gogol', and P.I. Iakushkin, and included material from practically every province of central Russia. (5) A.D. Soimonov claims that Kireevskii's first informant was his servant Rodion, from whom he took down folksongs while still studying in Germany [1971: 90-91]. A few years after his return, Kireevskii was in effect designated to coordinate a common effort that would bring together the best material in manuscripts and previous publications as well as songs that he and other contemporary collectors would provide. As late as 1832 Pushkin was planning to publish his own song collection, but by 1833 he was contemplating combining the efforts of the Iazykovs, Kireevskii, and others in creating a work of considerable proportion. Soimonov suspects that the decision to entrust this endeavor to Petr Kireevskii was adopted during a meeting which took place on 26 August 1833 in Moscow at the house of A.P. Elagina, the Kireevskiis' mother and the poet Zhukovskii's niece. Kireevskii, Pushkin, Pushkin's close friend S.A. Sobolevskii, and the literary historian S.P. Shevyrev were present [1971: 127-132]. Several months later Kireevskii informed his close friend the poet N.M. Iazykov that Pushkin promised to provide the preface to the collection [Kireevskii 1935: 50]. From the beginning, then, Kireevskii's project was thought of as a mutual effort and, to a good extent, he accepted the burden, on behalf of his generation, of ensuring that Russia's priceless folk heritage would be gathered and presented to the larger public before it was lost irrevocably. During the 1830 s he received a great deal of material from Iazykov, whom he consulted on publication plans and in October 1833 offered to make joint editor with his name appearing first on the title page [P.V. Kireevskii 1935: 51]. Virtually all of educated Russia was aware of Kireevskii's work, and many bemoaned his delay in getting his songs into print. Hampered by a somewhat lethargic disposition and periods of dejection following the censors' last minute 
rejection of the volumes that had been prepared, he succeeded in publishing very little during his lifetime [see Sokolov 1923: 23-24 and Soimonov, 1971: 290-304]. Yet, as Kavelin affirmed in his obituary of Kireevskii, "in spite of the fact that it appeared very rarely in print, his name was one of those known everywhere, both at home and abroad [vol. 2:1219]."

Kireevskii clearly perceived his task's historic dimension. From its early stages he viewed his folksong collection as a forceful rebuttal to those who derided Russia for lack of culture and tradition. The collection would, he believed, constitute living proof that Russians possessed strong historical memories enthroned in poetry and traditions. As he boasted in a letter of October 1833 to Iazykov, such a work would stun foreigners, whose own collections paled in comparison [1935: 48]. His letters often referred to P.Ia. Chaadaev, whom, he wrote, he did not consider Russian [1935: 33]. On 17 June 1833 he voiced his reaction to the ideas of Chadaaev's first philosophical letter, not published until 1836, but already well known within Moscow circles. Kireevskii's remarks foreshadow the heated debate of the following decade about Russian national identity:

Strongest embraces and thanks for getting me the songs! You have sent me treasures such as I didn't even expect. We can not only take pride in the richness and greatness of our folk poetry before all other peoples, but perhaps in this matter we shall surpass even Spain. [And this is true] despite the fact that there everything facilitated the preservation of folk traditions, while among us a sort of strange fate has struggled to erase them from memory. In the last 150 years especially, no fewer memories may have been destroyed than [during] the Tatar invasion. This cursed Chaadaevshchina makes me so furious that it often seems as though the entire great life of Peter has engendered more evil fruit than good. In its mindless self-adulation it rails over the graves of the fathers and tries to exterminate the entire great store of memories in order to set up in their place momentary wisdom [...] This sickly spiritual state has been squeezing and oppressing me for a long time, and the heap of songs that you sent is like a cool river in a stifling desert. With every hour I feel more intensely that the distinguishing, substantive trait of barbarity is absence of memory; that without a lively feeling of worthiness there is no great deed, no harmonious word; that there is no proper feeling of worthiness without national pride, and no national pride without national memory [1935: 42-43]. (6)

Chaadaev's articulation of the problem of national identity would agitate thinking Russians for the remainder of the century [Aizlewood 2000]. He claimed that Russians were isolated from the universal development of humankind and had failed to live through a period of 
historical adolescence that might have provided them with unifying memories and traditions; they now existed like strangers in their own house, like nomads, without links to other peoples, "in the narrowest of presents, without a past and without a future [Edie, Scanlan, Zeldin 1965: vol. 2, 109-11]." The nature of Russia's past and the direction of her future would constitute the nucleus of Slavophile-Westernizer debates within a few years: Could Russians take pride in a history that reached into the distant past and of what did this history consist? Or did their feeble attempts at nationhood begin only with Peter the Great? Was the real Russia preserved only among the people or did Peter's thrust westward place an insignificant people on the road to true nationhood and greatness? As M.K. Azadovskii remarked, both camps viewed folklore as "one of the most important elements of popular life without the analysis and study of which it was inconceivable to completely comprehend the historic fortunes of the country and the people [1958: 420]."

As Kireevskii's letters to Iazykov indicate, in the late 1830s and 1840s a good deal of the serious discussion about Russian national identity occurred in personal correspondence and face to face in Moscow literary circles, where the debate was especially heated in the years 18421845 [Brodskii 1910: 7]. Elagina's house was one of Moscow's major gathering places, and many members of the intelligentsia, including the Moscow Westernizers T.N. Granovskii, K.D. Kavelin, and A.I. Herzen, attended her Sunday evenings during these years. (7) Prior to his move to St. Petersburg in 1839 even V.G. Belinskii, who would soon become an uncompromising opponent, attended evenings with future Slavophiles and formed a close friendship with Konstantin Aksakov. In 1844, however, the mortally ill Iazykov wrote a poetic missive entitled "To those alien to us" ("К ненашим") insulting the Westernizers and rendering the meeting of the two camps under one roof far more difficult [Lilly 1972: 802-804; Herzen 1968: 546]. P.V.Annenkov remarked that discussion between the groups could be quite frank, yet distinguished the atmosphere of Elagina's home as restrained, humane and something of a neutral zone where opposing opinions could be expressed freely and without fear of scorn [1928: 332]. Guests included not only Westernizers and Slavophiles, but the historian M.P. Pogodin and literary scholar Shevyrev, whom Herzen dubbed the "Siamese twins of Moscow journalism" and the "government party [1968: 544, 543]." (8) Herzen's great opponent during these evenings was A.S. Khomiakov, to whom in jest he gave the nickname "Il'ia Muromets" since he behaved like a great 
"'bogatyr' who, on the side of Orthodoxy and Slavophilism, struck down everyone $[\ldots][\mathrm{H}] \mathrm{e}$ cut and thrust, attacked and pursued, pelted with witticisms and quotations, frightened his opponents and drove them into an enchanted forest from which there was no escape without saying a prayer ... [1968: 535]." Those who knew Petr Kireevskii from these gatherings recall his gentleness and purity of heart [Herzen 1968: 536; Kavelin 1897: vol. 2, 1221; Turgenev 1961: Письма, vol. 2, 130,185], his support of the most desperate Slavophile positions [Herzen 1968: 539-40], and his near duel with Granovskii following Iazykov's unfortunate poem [Herzen 1968: 546]. Herzen, interestingly, called both Petr Kireevskii and his more famous older brother Ivan "mournful shades" and suspected that their often dejected miens indicated that they had been "consumed by the rust of that terrible time" and "crushed and torn to pieces by the age of Nicholas [Herzen 1968: 537, 538]."

At these evenings the Slavophiles were intent on exalting the Orthodox Church and showing the unnatural and divisive nature of Peter the Great's reforms, which they believed had grafted artificial European manners onto the educated classes and erased any true recollection of indigenous Russian culture. But, they claimed, Old Russia had been preserved among the simple people. Curiously, Khomiakov and Konstantin Aksakov emerged as the primary folklore theorists among the Slavophiles, though neither contributed to Kireevskii's collection [Soimonov, 1971: 249-50]. (9) According to Soimonov, Khomiakov hoped to use Kireevskii's collection, especially the religious songs, as evidence for the Russian people's deep commitment to Orthodoxy. At the same time Khomiakov dismissed songs about peasant rebels and claimed that they were the result of a retreat from the primal unity between the people and their rulers, while anti-clerical tales, according to him, were due to ignorance [1971: 280-81]. Westernizers, who formed a less cohesive group of thinkers, admired Peter and Western civilization and tended to view the Orthodox Church as a reactionary institution in league with the oppressive regime. On balance, their attitude toward popular culture was more depreciatory than that of the Slavophiles [Annenkov 1928: 414-16]. Yet both groups had been nourished on German idealism, both abhorred government bureaucracy, and both believed that the system of serfdom needed to be eliminated. Nor did they necessarily agree within their own camps on all issues. In the company of a group of fellow Westernizers, Granovskii admitted that he was closer to the Slavophiles than to Belinskii in his views on Russian nationality [natsional'nost'] and various other literary and moral matters 
[Annenkov 1928: 409]. Ivan Kireevskii supposedly told Granovskii that, in his heart, he was closer to him but did not share many of his convictions; in religious belief he was nearer to the Russian people, but did not share much else with them [Herzen 1968: 538]. There is a good deal of truth in Herzen's well-known statement on the death of Konstantin Aksakov that both camps were possessed by the same powerful love "for the Russian people, the Russian way of living, the Russian cast of mind. And like Janus, or the two-headed eagle, they and we looked in different directions while one heart throbbed within us [1968: 549]."

M.N. Katkov's assault on Slavophile notions about pre-Petrine Rus', contained in his review of Sakharov's folklore collection Songs of the Russian Peорle (Песни русского народа, изданные И. Сахаровым) for Notes of the Fatherland in 1839, is generally regarded as the opening sally of the debate in print [Pypin 1911:122-27; Azadovskii, 1958: 42024]. Katkov continued his attack the following year in his review of Maksimovich's History of Ancient Russian Literature (История древней русской словесности), where he denied that Old Russia had any true written literature and asserted that "The Lay of Igor's Campaign” («Слово о полку Игореве») was worthless, without poetic value, and "impossible to accept as a genuine monument [1840: 67]." For Katkov the history of Old Russia constituted a series of purely external events, lacking inner spirit and coherence, but preparing the way for Peter the Great who, he argued, was called forth by Providence. In his review of Songs of the Russian People he contended that "Only since Peter have the Russian people [narod] become a nation [natsiia], become one of the representatives of humanity [...]; only since Peter have higher spiritual interests entered its organism [...]. But before Peter we had neither art in the proper sense of the word, nor science [1839: 8]."

Thus, Katkov, best known as the conservative editor of The Russian Herald (Русский вестник) in the 1860s and 1870s, began his journalistic career in the camp of the Westernizers, using his review of a folklore collection as a springboard for a long-winded overview of Russian history that exalted the role of Peter the Great. Katkov stressed the need for collecting folksongs, bemoaned the general lack of works like Sakharov's in Russia, and reproached Petr Kireevskii for delaying the publication of his material [1839: 9]. Unlike Aksakov and Khomiakov, Katkov treated folklore as an entity completely separate from Old Russian writings and proposed calling it "folk literature" [narodnaia literatura, 1840: 57, 43]. The Slavophiles placed particular reliance on 
the Primary Chronicle, which Konstantin Aksakov subsequently termed "the very first and most important foundation and source of information about the lives of the ancient Slavs, and especially the Russians [1852: 99]." In his review of Sakharov, Katkov belittled the chronicle as a motley collection of stories containing a good deal of fabrication and derided scholars who scoured dusty archives looking for the meaning of ancient Rus' [1839: 32]. Instead, he asserted, they should turn their attention to folksongs; "in them our Rus' is alive; [...] in them is reflected the power, the expressive countenance of a great people (narod), with all its natural beauty, (just) as God created it! [7]." Katkov described the inner life of the Russian soul as a "bitter, melancholy feeling of indefiniteness and a certain vague dissatisfaction [38]" occasioned by a history of extreme suffering. He found reflections of this state in the tendency of Russians to both despondency and unbridled debauchery. The plaintive sounds of many lyric songs, especially those concerning the hard lot of women, reflected this dejection, he claimed [76-82]. By contrast, he found the world of the epics open, bright and cheerful [57], and distinguished their main trait as the idealization of physical strength [sila]. But he cautioned against looking for real history in epics, since it is here that "the Russian soul fled from the storm of reality to rest and take comfort [65]." Interestingly, in distinction from Aksakov and Khomiakov, who argued that religious songs [stikhi] manifested the fundamental Christianity of the Russian people, Katkov discerned in them an underlying layer of paganism. Here he unwittingly repeated a view similar to one that Petr Kireevskii had voiced in a letter of September 1832 to Iazykov: "Just as many of the shrines of the ancient world escaped destruction by putting the Christian cross on their roofs, so too many of our pagan traditions have been preserved by attaching themselves to songs about saints... [Kireevskii 1935: 23]."

According to Katkov, folk poetry constituted the fullest expression of the inner life of a people at its primitive stage and, as a people developed, newer and higher forms emerged. As a result, what formerly was characteristic of the people as a whole became characteristic only of the "simple people" [to, cho prezhde bylo narodnostiiu, niskhodit na stepen' prostonarodnosti, 25-26]. Here Katkov alluded to the split in Russian society that occurred since Peter the Great. Contrary to the Slavophiles, who lamented the loss of what they felt was most authentic in Russian life, he viewed the changes as an infusion of vital new forces and did not exclude the upper classes from the designation "narod." Rather, he regarded the upper layer of society as the vehicle through 
which the whole people "accomplishes its purpose, expresses the idea to which it was summoned [26]." The educated classes would now be the bearer of a genuine art that would gain world fame, and the old forms of "natural" poetry belonging to the simple people [prostoi narod] would no longer be sufficient for them [26]. This schema explains in part Katkov's high praise for M.Iu. Lermontov's "Song of the Merchant Kalashnikov" ("Песня про царя Ивана Васильевича, молодого опричника и удалого купца Калашникова"); in his opinion, the writer elevated the cruder elements of folk fantasy to the level of first-rate literature [75-76].

Katkov's conceptualization of the movement from folk poetry to literature as an evolution from a lower form to a higher one which would take place within the context of national development drew heavily on the Hegelian dialectic. As D.I. Chizhevskii remarks, the Russian Hegelians of the 1840s, who included for a time not only Katkov, but also Belinskii, and Konstantin Aksakov, tended to "place their particular subject within a broad, primarily philosophical- historical context [1939: 171]." Katkov in fact provided Belinskii with a summary of Hegel's lectures from which the latter, though already acquainted with many of the philosopher's ideas, familiarized himself with his aesthetics [Chizhevskii 1939: 131; Terras 1974: 95]. In both Katkov's and Belinskii's assessments, folklore is perceived as the "literature" of an early state of human existence, which, as society develops and becomes more enlightened, becomes increasingly the property of the lower strata and less historically relevant [Terras 1974: 95, 59-69 and elsewhere; see also Azadovskii, 1958: 440-43]. But though they shared an overall philosophical schema, Belinskii's and Katkov's understandings of particular works of folklore did not always coincide. (10)

Belinskii is generally considered the first Russian critic to provide a genuine theoretical framework for Russian folk poetry [Terras 1974: 95; Azadovskii 1958: 441]. Though Katkov collaborated with Belinskii for a period on Notes of the Fatherland, he left for Germany in late 1840 and abandoned the journal's liberal bent [see Katz 1966: 21-31; Sementkovskii 1891: 12-15; and Annenkov1928: 266]. Belinskii's most important treatment of folk poetry consisted of a series of essays that appeared in the last four issues of Notes of the Fatherland for 1841 and purported to review the second edition of Kirsha Danilov's Ancient Russian Songs, M. Sukhanov's supplement to Kirsha Danilov, Ancient Russian Songs (Древние русские стихотворения, 1840), the third edition of I. Sakharov's Tales of the Russian People (1841) and Russian Folk Tales (Русские народные сказки, Part 1, St. Petersburg, 1841). 
To grasp Belinskii's argument, one must understand his critical lexicon, especially the words narodnost', prostonarodnost' and natsional'nost'. Narodnost' represents the uniqueness of one's own people [narod] and, in combination with the human [chelovecheskoe], is a necessary component for great art: "the only literature that is genuinely narodnaia is that which is at the same time common to all mankind (obshchechelovecheskaia); and the only literature that is genuinely human (chelovecheskaia) is that which is simultaneously narodnaia [1955: vol.5, 306]." Belinskii insisted that if a people (narod) has become historically significant 'its narodnost' must exist in form only, must be the manifestation of the human idea, but not the idea itself [vol. 5, 306]." Prostonarodnost' implies an attempt to capture the language, customs, or dress of a people without capturing their inner essence. Belinskii complained that in recent Russian literature "such falsely understood narodnost' has gushed forth like a huge swamp. Peasant men and women, coachmen, bearded merchants have not only received the right of citizenship, [...] but have been made the only privileged heroes. A successful imitation of the language of the mob, the jargon of village squares and cook shops has become the sign of narodnost'... [5: 299]." Natsional'nost' is related to the concept of "nation" [natsiia], and Belinskii believed that Russia started on the path toward nationhood only with Peter. According to his understanding, great art must be simultaneously "natsional'noe" and "narodnoe" and only a great nation could produce such art [vol. 5, 301; see also Terras 1974: 94 and Azadovskii 1958: 445].

For Belinskii, folk poetry represented the expression of the adolescent stage of a people who had yet to acquire world significance and become a nation [natsiia]. Literary productions, he contended, were far more artistic than those of the folk: "one small poem of a genuine poet-artist is immeasurably greater than all works of folk poetry put together [vol. 5, 309]." In his opinion, the integrity of an artistic work depended on the resolution of the tension between naturalness [estestvennost'] and artificiality [iskustvennost']; yet, he emphasized, naturalness and narodnost' are not equivalents [vol. 5, 301]. He distinguished the two great epochs in the life of a nation as the epoch of natural immediacy and the epoch of conscious existence [vol. 5, 308] and claimed that a "people that has not yet awakened from the natural state to one of self-consciousness can have folk [narodnye] poems and songs only; they cannot have poets, and especially great poets [vol. 5, 331]." (11) Prior to Peter the Great, he maintained, Russian popular poetry and 
daily life displayed an abundance of vitality and was "entirely capable and entirely worthy of becoming a vessel of an immensely great soul, but deprived of this soul could only await it and seek it [vol. 5, 399]."

Belinskii acknowledged the allure of plaintive folksongs reflecting the inner life and daily hardships of the people [vol. 5, 329], and he strongly encouraged collecting efforts. But he had a low opinion of Kievan epics. He used the term "skazki" in reference to them because he felt that they were not true poems. In a real poem, he stated, the poet places the subject higher than himself and evokes admiration for it. Epics from the Kievan cycle fail to do this and are pure entertainment with a good deal of prosaic expression and prostonarodnost' [vol. 5, 354]. In distinction to Katkov, he found no trace of dual faith in the Kievan cycle, which he wrongly dated to the period following the Tatar Yoke, and he regarded "The Lay of Igor's Campaign" as far more artistic than oral epics because he discerned in it the stamp of the poetic and human spirit of Southern Rus' [vol. 5, 332-33]. His treatment of the poems themselves consisted mostly of retellings interspersed with comments. In his opinion, the Kievan epics lacked distinct images and historical significance and their overall emphasis was on physical strength "triumphing over all obstacles, even good sense [5:398]." Regarding the supposed heroic quality of the byliny he remarked:

\footnotetext{
"Heroism is the first stage of a people's awakening awareness of life. And savage, animal strength, the strength of an iron fist or pig-iron skull is the first stage of a people's consciousness of heroism. This is why among all peoples heroes gobble up entire bulls, snack on rams, and drink barrel after barrel [of wine]. But a people in whose life the [notion of the] commonly human (obshchee) develops moves on further, and the second stage of its awareness of heroism is the illumination of the animal force by sense of duty, truth, and valor. Our folksong singing stopped on the first stage and did not develop further. Therefore our epic heroes (bogatyri) are shades, phantoms, mirages, and not definite images, not characters, not defined ideals. They have no notions of valor and duty, and any form of service is acceptable to them, any act of daring is for them a feat (podvig) be it conquering an entire army and trampling it with their horses or drinking an entire pail of green wine in one gulp ... [vol. 5, 398].
}

While Katkov viewed the epics as an escape from reality, Belinskii sought in them indications of the historical situation of ancient Russia. He saw the Kievan cycle as reflecting the dismal status of women, the emphasis on brute strength untempered by reason, and drunkenness and the Novgorod cycle as showing faint glimmers of civic awareness. No doubt it was this embryo of civic awareness that caused Belinskii to rank 
the Novgorod epics far higher in spirit and content than the Kievan ones. Here, he claimed, one sees in the new and special world of the city of Novgorod "a prototype of Russian civilization and generally of the forms of social and family life of ancient Rus' [vol. 5, 401]."

Belinskii's articles display a condescending attitude toward folklore. (12) In part this can be attributed to his Hegelian schema which assigns folklore to a phase of development that would be transcended as a people progressed toward genuine nationhood and true (literary) art. In addition, Belinskii was generally known for contemptuous outbursts about peasant life, which he called a "bast shoe and homespun reality [Annenkov 1928: 333]." Both Westernizers of his own time and Soviet critics tried to soften his negative attitude by attributing it to his indignation at the extent to which centuries of oppression had demoralized the people [Azadovskii 1958: 451, 454; see also Terras 1974: 95-96]. There is some merit to this argument. By the time he wrote his essays on folk poetry, Belinskii had entered the final stage of his development as a critic: he had become uncompromisingly hostile to the regime of Nicholas I and had come to view literature as a weapon in the struggle for social justice. (13) His abhorrence of serfdom and despotism prompted him to assess folk epics, not on the basis of their artistic merit, but according to what he perceived as their underlying social code and he came to prefer the faint glimmers of freedom in the Novgorod cycle to the affirmation of a patriarchal and princely hegemony in the Kievan songs.

Belinskii's derisive attitude toward peasant culture exerted a significant influence on others. In the late 1840 s even F.M. Dostoevskii echoed the critic's negative sentiments about folklore, though by the 1860 s and 1870s he would, like the Slavophiles, speak of the epic hero Il'ia Muromets as embodying the exalted religious ideas of the people [Ivanits 515, 521-22]. Among the Westernizers, K.D. Kavelin constituted an exception to this scornful outlook [Annenkov 1928: 416-17]. A liberal with close friends among the Moscow Slavophiles, Kavelin collected folklore and contributed material from various provinces to Kireevskii's collection [see Gladkikh 1996: 88-91]. After moving to St. Petersburg he continued his folklore work as a member of the Russian Geographic Society where he organized material coming into the archives and worked on the publication of various ethnographic miscellanies. He called for a more rigorous and historically grounded methodology in folklore studies and, in an 1848 review, soundly criticized Tereshchenko's Daily Life of the Russian People for its lack of a scientific approach [see Gladkikh 1996: 93-96]. Kavelin's folklore 
activities acquainted him with the actual life of the Russian peasantry and later served him well in his work toward the emancipation of the serfs. (14)

The Slavophiles constituted a fairly homogenous group. They came from gentry backgrounds and tended to idealize the Russian narod and the ancestral way of life that they sought to maintain on their estates. Khomiakov expressed their general attitude toward folklore in his preface to the four songs from Kireevskii's collection included in the Moscow Miscellany (Московский сборник) for 1852. According to him, in the people's songs and tales "the olden times (starina) live powerfully and freshly [1852: 324]." Konstantin Aksakov termed the peasant "the best person" in Russia [Azadovskii 1958: 379]. Aksakov was easily the most extreme of the Slavophiles [Walicki 1975: 238], and Pypin was probably right in terming him an "armchair" folklorist who "hovered in the realm of theoretical and poetic constructions where, unconfronted by reality, ideals remote from life are easily created [1891: vol. 2, 204]." Though he often dressed in peasant costume, it appears that he seldom actually ventured into the village to collect songs, and was thus different from his younger brother Ivan who wrote down a number of songs while on government assignment to investigate sectarians in Iaroslavl' Province [see Brodskii 1922: 6-9].

For his master's dissertation, "Lomonosov in the History of Russian Literature and the Russian Language" («Ломоносов в истории русской литературы и русского языка»), which was written in the early $1840 \mathrm{~s}$ and published in 1846, Konstantin Aksakov adopted a Hegelian framework. He characterized the pre-Petrine period of Russian history as one of exclusive nationality [natsional'nost'] and one-sidedness, manifested in folksong, which, he claimed, reflected common and national, but not individual emotions and situations:

Folksong reflects the life of the people, and the people only [...]. There is no common human content here $[\ldots]$; there is no individual, personal life $[. .$.$] .$ $[\mathrm{F}]$ or this reason, folksong belongs to all the people equally; that is why the entire people sing folksongs and why all people have equal right to such songs; that is why a folksong does not bear the name of its composer [...] The entire substance of the people, with all its depth and richness, with all its many attributes, is reflected in such poetry, but it is limited to national (narodnaia) substance only. The people (narod) appear as a unit, a mass that consumes the individual $[. .$.$] There are no poets here; the poet is the people$ $[$ narod $][\ldots]$

As the period of exclusive nationality passes, the individual is set free, and the human being in general is set free at the same time. [...] In ceasing to be 
exclusive, nationality [natsional'nost'] loses nothing; on the contrary [...] it is elevated [1981a: 41-43]

Aksakov's text presents Peter the Great as a pivotal figure who exposed and struck down Old Russia's one-sidedness [31]; in literature Lomonosov represented the parallel to Peter, since he embodied the transition from mass consciousness to individuality [36]. This schema assumed the necessity of forward movement in history, rendering Peter a positive figure. Of course, within Slavophile dogma the notions that Old Russia needed to change and that Peter represented a constructive force constituted heresy, and Aksakov subsequently abandoned Hegel, most likely under the influence of Khomiakov [Azadovskii 1958: 385].

Yet several pages of his dissertation contain the standard Slavophile teaching about Il'ia Muromets. These pages were inserted in place of a section removed by the censor that was to expound the need for a new turn in the direction of national consciousness, a section that criticized Peter's as turning away from Russian history and literature toward that which was foreign [Aksakov 1981a: 31; see Pypin 1891: vol. 2, 195, footnote 1; Azadovskii 1958: 384]. Emphasizing Il'ia Muromets' Christianity and peasant origin and insisting on the interchangeability of the words "Christian" [khristianin ] and "peasant" [krest'ianin, 51], Aksakov viewed him as a manifestation of the true spirit of the people [narod]:

The esteemed assembly of heroes that gathered around the great Kievan prince Vladimir is great and diverse; they all express the many sides of the Russian spirit. But of all of them the most powerful is the chosen one of the Russian people Il'ia Muromets. The Russian spirit [...] is expressed foremost in him. He alone is old among the young; he alone is free from rivalry. The story of how he was a cripple for thirty years is remarkably well-known to every Russian. It points to the essence of the Russian spirit, captures the image of the people itself, which also, like Il'ia Muromets, stored up its strength during the period of exclusive nationality and will rise above other nations just as the bogatyr' Il'ia Muromets rose above the other bogatyri. He stored up terrible strength and he arose and assumed its power, but not to insult and destroy others, not for the wanton spilling of blood, but rather for the defense of good and the defeat of evil, for peace and tranquility. Let's look more closely at Il'ia Muromets, at this image of the Russian people. First of all he is a peasant; he arose from the depths of the Russian land, from where the pure source of faith and simple life springs. Among the other bogatyri, some are well-known heroes of high birth, some are relatives of Vladimir, and so forth. Il'ia Muromets alone is a peasant, and he is greater and stronger than everybody. This constitutes a very important and fundamental trait of his image. In him there is no frenetic boldness and daring, as in the other bogatyri ...; he is quiet and tranquil and quietly 
powerful. Only when necessary does he manifest his insuperable might [1981a: 50-51].

Khomiakov echoed the above sentiments about Il'ia Muromets in his preface to the songs from Kireevskii's collection in the Moscow Miscellany. He termed the hero's strength "unconquerable, always in the service of good sense and duty, a noble strength, full of belief in the help of God, alien to passions, and tied to the land from which he emerged with unbreakable bonds. And isn't it precisely this Russian land that Russian singers have unconsciously used as inspiration and personified in him? [1852: 331]." Shevryev bolstered the Slavophile Christianization of the folk epic and the exaltation of Il'ia Muromets in his lectures on Russian literature at Moscow University in the mid 1840s. He taught that in the epic heroes the Russian people [narod] had embodied its two greatest feats: the defeat and eradication of the Asiatic hordes and the annihilation of paganism and sorcery [1887: 131]. Interestingly, the Slavophile notion of Il'ia Muromets as the model of an unselfish yet mighty hero, representative of the true spirit of the people and devoted to his native land has proved tenacious. It even prevailed in the Soviet period, without its extreme Christian overtones of course [see Astakhova 1958: 393-98 and elsewhere].

In Konstantin Aksakov's view, it was possible to bring the prePetrine past into the present. He advocated not a return to what had ceased to be, but turn to what, he alleged, actually existed in the mindset and customs of the simple people [see Azadovskii 1958: 378-79]. Here he had in mind not only Orthodoxy, but also the communal organization of village life [obshchina], which he detected in the arrangement of the heroes of the Kievan epics around Vladimir's table. (15) To him, the diverse social composition of the bogatyri (consisting of the peasant Il'ia Muromets, the aristocrat Dobrynia Nikitich, the cleric Alesha Popovich, the merchant's son Ivan, and so forth) and the inclusion of women at the feast was a reflection of the actual social structure of ancient Russian life. This, along with the overall balance between personal freedom and willing service to the prince was an ideal that he promoted ["Bogatyri" 1981b: 93]. Moreover, he contended, "Christianity is the main basis of Vladimir's entire world. [...] These feasts, this way of life also have an all-Russian significance: we see the entire Russian land assembled in one place, gathered together by the Christian faith into a single unit centered around the grand prince Vladimir, the enlightener of the Russian land [1981b: 94-95]." 
One must question the extent to which Petr Kireevskii genuinely agreed with the positions that Khomiakov and Konstantin Aksakov took regarding folklore. Mention of Kireevskii's collecting work receives minimal attention in Annenkov's and Herzen's recollections of him, and one suspects that he preferred not to make elaborate speculations about the meaning of folklore during evenings at his mother's house [Kavelin 1898: vol. 2, 1220 gives a good deal more information about Kireevskii's life's work in his obituary]. Soimonov thinks that Petr Kireevskii suffered inner turmoil because of "the incompatibility of the Slavophile doctrine, which he shared, to the materials of his folklore collection [279]." The remarks Kireevskii made in his articles, letters, and public statements suggest that we should take Soimonov seriously. As noted earlier he glimpsed remnants of pre-Christianity behind the images of some saints found in religious songs (stikhi). Religious considerations were evidently not the motivation for his urging Iazykov, in a letter of 21 April 1837, to collect stikhi as quickly as possible. Rather, he feared that these songs would disappear quickly because a new regulation had been issued reclassifying the beggars who sang religious songs and designating them vagrants [1935: 74-75]. On the basis of his materials he surely knew that peasants revered not only Il'ia Muromets, but also bandits and peasant rebels such as Razin; a number of songs about Razin appear in his collection [1868: vol. 7, 32-43]. We can also infer that he disagreed with Aksakov's contention that village life and folklore constituted a replication of the olden times in the present. Kireevskii, in fact, suspected that many of the best folksongs belonged to an irretrievable past. As he phrased it in a lecture he delivered in 1848 at Moscow University: "It is possible to compare Russian songs with a magnificent tree still full of strength and beauty, but already cut down. The innumerable branches of this tree are still covered with fresh foliage; its flowers and fruit still exude the fragrance of the fullness of life. But already there are no new offshoots, no new buds that will yield new flowers and fruit [quoted from Soimonov 1971: 250]."

Petr Kireevskii, of all his contemporaries, no doubt had the most extensive knowledge of the Russian folksong repertoire and its characteristics. Yet he seldom theorized about folklore and on occasion seems to have deliberately ceded folklore commentary to others. The third issue of The Muscovite for 1845 included two open letters to Pogodin protesting his emphasis on the supposed meekness and docility ancient Russians manifested in accepting Norman rule. The historical argument fell to Petr Kireevskii, who developed his objections on the 
basis of the chronicles, while the task of correcting Pogodin's misconceptions about folk poetry fell to Maksimovich. Defending the Slavophile position that the leadership of Riurik represented continuity, not submissiveness and indifference, and was grafted onto an already existing political-social system, Kireevskii wrote: "One must admit that [...] a people [narod] who submit peacefully to the first invader who comes along, who accept alien rulers without any resistance, whose distinguishing trait is unconditional submissiveness and indifference, who even deny their faith when ordered to do so by alien rulers, could not evoke great sympathy. Such a people would be devoid of all spiritual strength, of all human dignity, cast off by God, (they would be a people) from whom nothing great could emerge [1845: 13-14]." Kireevskii cites the resistance to foreign invaders that the Russians showed during the Tatar Yoke, the Time of Troubles, and the War of 1812 as evidence of their lack of docility. The second instance concerned the Moscow Miscellany in 1852, where, as already noted, Khomiakov supplied the preface to the four songs from Kireevskii's collection, approaching them from an ideological rather than aesthetic perspective. He offered the standard Slavophile understanding of Il'ia Muromets; found Christian meaning in a song about a bandit who, though belonging to the worst class of criminals, might still repent; but completely ignored wedding poetry. Kireevskii's afterword to the same texts seems totally disconnected from Khomiakov's preface; it makes no mention of Christianity and uses a different term for byliny (Khomiakov called them "skazki," while Kireevskii included them under "historical songs"). Kireevskii contended that conditions for preserving historical songs worsened at the beginning of the eighteenth century and designates Peter as the dividing line between the songs of higher artistic value and the newer, less successful ones. At the same time he notes that songs are still being created among the Don and Volga Cossacks. This seems to be an allusion to songs about Razin and Pugachev. Kireevskii mentioned the absence of songs about the Tatar Yoke from his considerable collection and concluded that the people had preserved only the memory of the bright side of Ivan the Terrible's reign [1852: 355-56]. (16)

On balance, then, Slavophiles sought evidence of the people's Christian and communal essence in folksongs, though this position seems to have enjoyed half-hearted support from Petr Kireevskii. Westernizers looked to songs for signs of the cultural inadequacy and oppressed status of the peasantry. Belinskii's relegation of folklore to a subordinate position in Russia's development complemented his belief that the 
people needed to make the transition from ignorance and crudeness to political consciousness and responsibility and that the educated members of society needed to guide them [see Terras 1974: 94, 100]. Given the severe censorship of the era, he could only hint at these sentiments in print. But they were clearly stated in his widely-circulated letter to Gogol', where he insisted that Russia's salvation lay not in mysticism or asceticism, but in civilization, enlightenment and the awakening in the people of a sense of human dignity. For him the most pressing national concerns were the abolishment of serfdom and corporal punishment and the strict observance of those laws that were already in existence [1955: 10: 213]. He denied that the people and their folklore were fundamentally Christian, remarking: "About whom does the narod tell dirty stories? About the priest, his wife, his daughter, and his worker. [...] The Russian man utters the name of God while scratching his rear end. He says of the icon: if it's not good for praying, then it's good for covering the pot. [...] In them [the people] there is a great deal of superstition and not even a trace of religiosity [10:215]." These general lines of Slavophile and Westernizer thinking about the people and folklore would, of course, continue throughout the century.

In marshaling songs to the support of their ideological agendas, Aksakov, Khomiakov and Belinskii all neglected the artistry of the texts. But this was by no means true of all Slavophiles and Westernizers. Petr Kireevskii, Kavelin, and a number of other collectors seemed motivated largely by the allure of the songs themselves. Kireevskii, despite difficulties in publishing his material, stood at the center of a huge national enterprise which involved many educated Russians of his generation and, through his work with students at Moscow University, prepared the next generation of collectors and scholars, who would help establish Russian folklore as a discipline in its own right. P.I. Iakushkin, who worked closely with him during the last decade of his life, was no doubt the most prominent of them (17).

Under Nicholas I lively interactions took place among folklorists and between collectors and writers, a good number of whom also gathered folksongs. Kireevskii gave Snegirev material relating to popular celebrations and beliefs and received folksongs in return; Dal' gave Kireevskii songs, some of which he received from Pogodin, in exchange for proverbs, sayings, and folktales, some of which had been transcribed by Iakushkin and eventually found their way to Afanas'ev's collection [Soimonov 1971: 209-10; 230]. Dal' assisted Pushkin and gave him songs when the latter journeyed to Orenburg to gather information about 
Pugachev [Blagoi et al. 1968: 443]. Pushkin, N.V. Gogol', Dal', and A.V. Kol'tsov all contributed to Kireevskii's collection [Blagoi et al. 1968]. Azadovskii affirms that Lermontov was familiar with material from Kireevskii's archive. He visited him in Moscow in early 1837 and likely acquainted himself with a song from the Simbirsk province about "two Kulashnikovs," from which he derived the name "Kalashnikov" used in his own work [Azadovskii 1960: 238-39]. Turgenev was well acquainted with the Aksakovs and seems to have received material regarding sectarians from Ivan Aksakov, which he used for his work on Notes of a Hunter (Записки охотника, 1852) [Brodskii 1922: 6-9]. The writer also became acquainted with Kireevskii in the early 1840s through the Elagina salon, and they subsequently visited each other's estates. Turgenev was familiar with Kireevskii's work and may have seen some of the latter's variants of the songs he used in "The Singers" («Певцы»), one of the most beloved sketches from Notes of a Hunter [Azadovskii 1960: 425; see also Soimonov 1971: 275-78]. Thus, though publication of folklore material was difficult and a solid methodology and "science" of folklore had yet to be developed, the period's vast collecting efforts and networks of personal interactions rendered it rich in a different way. It prepared fertile soil for the burst of folklore activity and publications of the 1860 s and 1870 s.

\section{NOTES}

1 The present essay is part of the introductory material for a book in progress on folklore and national identity in Russian literature during the reign of Nicholas I.

V.G. Bazanov offers an illustration of the prohibition of bandit folklore in the Tula Provincial News (Тульские губернские ведомости) in 1848. The censorship committee concluded that it would be better to cease publishing legends of the daring deeds and buried treasure of local bandits, especially of Kudeiar. Their argument was that if such legends were fostered among the people they would work against government interests, and since provincial newspapers were official publications, their purpose must be the dissemination of useful ideas or "at least not harmful, and not of such mindless fables ...[1973: 266, footnote 3, quoted from TsGAOP, f. 100, op. 1, No 99, 1. 4].” But censorship was quite inconsistent, and in the case of the Saratov Provincial News (Саротовские губернские ведомости), bandit songs escaped the attention of the authorities, who focused their attention instead on songs 
about unequal and forced marriages. N.I. Kostomarov's folk song collection, which had been appearing for several years, was forced to cease publication since these songs allegedly presented "the criminal and sorrowful side of peasant life, and in particular the anguish and despair of husbands whose wives had become hateful to them and who sought satisfaction and contentment outside family life [Alekseeva 1962: 274, 275]."

2 The term "folklore" was not used in Russia until the very end of the nineteenth century. See Ryan, 2006: 13, footnote 29.

Berlin, 1978; Bowman, 1954; and Riasanovsky, 1965 contain almost nothing on folklore. Terras, 1974 summarizes Belinskii's folklore articles, and Walicki, 1975 briefly mentions folklore in Aksakov's dissertation on Lomonosov. He also notes Belinskii's negative attitude toward folklore reproductions, but does not discuss folklore as a topic of Westernizer-Slavophile debates. Neither the introduction to a selection of critical works from the 1840s and 1850s by Kantor and Ospovat, 1982, nor the study of Belinskii's argument with the Slavophiles by Tikhonova, 1999, contains anything on folklore.

3 For more complete bibliographic information see Azadovskii 1958: 176-79, 235-37, and elsewhere; for folktales see Novikov 1961 and 1971; for folklore in The Muscovite see P. Bartenev, 1855. "Index of Articles and Materials about Folklore Published in The Muscovite from 1841 to 1855" (Указатель статей и материалов по фольклору и этнографии России, помещаны в «Москвитянине» за 1841-1855 годы).

4 One should perhaps mention the inexhaustible efforts of V.I. Dal', who belonged to neither the Slavophile nor the Westernizer camp. The vast material he gathered entered his dictionary, his collections of proverbs and superstitions, as well as the collections of others, most notably A.N. Afanas'ev's Russian Folktales (Hародные русские сказки) and Russian Folk Legends (Народные русские легенды). See, e.g., Vlasova 1976 and Blagoi et al. 1968: 441-448. Also beyond the scope of the present paper is the folklore work of other Slavic nations, especially Ukrainians, and their interactions with the Russians. See, e.g., Azadovskii 1958: 255-327 and Soimonov 1968.

5 For a treatment of the writers who contributed to Kireevskii's archive see Blagoi, et al., 1968.

6 Translations are my own except for those from Herzen.

For Chadaaev's take on Peter the Great, see McNally, 1964. 
7 Azadovskii 1960a ["Narodnaia pesnia"]: 314, emphasizes that in the 1840s Slavophiles and Westernizers, including Belinskii, who by 1840 lived in St. Petersburg, were generally aware of each other's verbal statements and letters as well as of material that appeared in print. Soimonov 1971: 49 indicates that the secret police had placed Elagina's evenings under supervision. Regarding the all-encompassing nature of the Slavophile-Westernizer debate in Moscow salons in the early 1840s Herzen wrote, "The arguments were renewed at every literary and nonliterary evening at which we met, and that was two or three times a week. On Monday we assembled at Chaadayev's, on Tuesdays at Sverbeyev's, and on Sundays at Madame A.P. Yelagin's [1968: 535]."

8 On Pogodin and Shevyrev as official nationalists rather than Slavophiles see, for example, Thaden 1964: 23; see also Thaden 1999, 90-101.

9 In 1838 Khomiakov may have helped draft Kireevskii's public appeal for folksongs ("Pesennaia proklamatsiia"), which was published in several provincial newspapers [see Soimonov 1971: 169-71].

10 Azadovskii tries to distance Belinskii's position on folklore from that which Katkov expressed in his review of Sakharov and claims that, even in his early articles, Katkov displays a tendency toward archconservatism [1958: 421-24].

11 Both Katkov and Belinskii considered the Greeks an exception to this law of development; true art existed among them from the beginning [see Katkov 1839: 23-24 and elsewhere].

12 Azadovskii tries to attribute the impression that Belinskii viewed folklore negatively to his harsh criticism of Pushkin's skazki as an example of false narodnost' [1958: 435 and elsewhere]. Interestingly, while rejecting Pushkin's folktales, Belinskii, like Katkov, enthusiastically welcomed Lermontov's "Song of the Merchant Kalashnikov" [Azadovskii 1958: 451].

13 See Chizhevskii 1939: 134-39, Terras 1974: 197-98, and Bowman 1954: 106-39 for a discussion of Belinskii's middle period (1839-40) of reconciliation to social reality, based on a misinterpretation of Hegel's proposition that "all that is real is rational."

14 See Field 1973: 64-69 for Kavelin's part in preparing for the emancipation and Wortman 1962 for the part played by liberal Slavophiles including Iurii Samarin.

15 The notion of the obshchina as the primary organization among the early Russians was an idée fixe with Aksakov. His chief opponents among the Westernizers were D.K. Kavelin and S.M. Solov'ev, who 
argued for organization on a kinship (clan) model. This subject is outside the scope of the present essay. For more information see Offord 1985; Thaden 1999; Korsakov 1896; and Prilenskii 1995.

16 P.I. Iakushkin, who served as Kireevskii's close collaborator from the mid 1840s until his death, later found songs presenting a negative image of Ivan the Terrible in the Pskov and Novgorod regions [Zemlianova 1958: 190].

17 Kireevskii entrusted the task of preparing his material for publication after his death to Iakushkin. Iakushkin worked on the material according to the plan left by Kireevskii for about a year, but was removed from the project in favor of P.A. Bessonov. See Balandin 1969: 57-95 and, for Iakushkin as a political radical, Gleason 1980.

\section{BIBLIOGRAPHY}

Afanas'ev, A. N. 1858. Афанасьев, А.Н. Народные русские сказки [Russian Folktales]. Москва: Изд. К. Солдатенкова и Н. Щепкина.

Afanas'ev, А. N. 1859. Афанасьев, А.Н. Народные русские легенды [Russian Folk Legends]. Москва: Изд. Н. Щепкина и К. Солдатенкова.

Aizlewood, Robin. 2000. "Revisiting Russian Identity in Russian Thought: From Chaadaev to the Early Twentieth Century," Slavonic and East European Review, vol. 78, no. 1, pp. 20-43.

Aksakov, K. S. 1852. Аксаков, К.С. «О древнем быте у славян вообще и у русских в особенности (по поводу мнений о родовом быте) » [“'On the Ancient Way of Life of the Slavs in General and the Russians in Particular (Apropos of Kinship Customs)"]. Московский сборник, Москва: Семен, 51-139.

Aksakov, K. S. 1981a [1846]. Аксаков, К.С. «Ломоносов в истории русской литературы и русского языка» ["Lomonosov in the History of Russian Literature and the Russian Language"], К.С. и И.С. Аксаков, Литературная критика, Москва: Современник, 30-89

Aksakov, K. S. 1981b [1856]. Аксаков, К.С. «Богатыри времен Великого Князя Владимира по русским песням» [“Еpic Heroes of the time of Great Prince Vladimir according to Russian Songs"], К.С. и И.С. Аксаков, Литературная критика, Москва: Современник, 89-139. 
Alekseeva, О. В. 1962. Алексеева, О.Б. «Из цензурных материалов о народных песнях» [“From Censored Materials about Folk Songs"]. Русский фольклор (Материаль и исследования), т. 7, 374-76.

Annenkov, P. V. 1928 [1881]. Анненков, П.В. «Замечательное десятилетие (1838-1848)» [“The Remarkable Decade"] Литературные воспоминания [Literary Memoirs]. Ленинград: «Academia», 161-601.

Astakhova, А. М. 1958. Астахова, А.М. «Илья Муромец в русском эпосе» [“Il'ia Muromets in the Russian Epic,"]. Илья Муромеи, Москва и Ленинград: АН СССР, 393-419.

Azadovskii, М. К. 1958. Азадовский, М.К. История русской фольклористики [The History of Russian Folkloristics]. Москва: Учпедгиз.

Azadovskii, М. К. 1960a [1941]. Азадовский, М.К. «Фольклоризм Лермонтова» [“Lermontov's Folklorism”]. Статьи o литературе $u$ фольклоре, Москва и Ленинград: Государственное Издательство художественной литературы, 212-59.

Azadovskii, М. К. 1960b [1950]. Азадовский, М.К. «Народная песня в концепциях русских революционных просвитетелей 40-х годов» ["The Folksong in the Conceptions of Russian Revolutionary Enlighteners of the 1840s"]. Статьи о литературе u фольклоре, Москва и Ленинград: Государственное Издательство художественной литературы, 305-40.

Balandin, А. I. 1969. Баландин, А.И. П.И. Якушкин: Из истории русской фольклористики [P.I. Iakushkin: From the History of Russian Folkloristics], Москва: Наука.

Bazanov, V. G. 1973. Базанов, В.Г. От фольклора к народной книге [From Folklore to a Popular Book]. Ленинград: Художественная литература.

Belinskii, V. G. 1955 [1841, 1847]. Белинский, В.Г. Полное собрание сочинений [Complete Works]. Москва: АН СССР, тт. 5, 10.

Berlin, Isiah. 1978. Russian Thinkers, ed. Henry Hardy and Aileen Kelly, London: The Hogarth Press

Bessonov, P. А. 1861. Бессонов, П.А. Калеки перехожие [Wandering Beggars] Москва: Семен.

Blagoi, D. D., A. S. Bushmin, V. V. Vinogradov, et al. (eds.). 1968. Благой, Д.Д., А.С. Бушман, В.В. Виноградов, и др. (ред.). Песни, собранные писателями: Новые материаль из архива П.В. Kиреевского [Songs Collected by Writers: New Materials 
from the Archive of P.V. Kireevskii]. Литературное наследство, т. 79, Москва: Наука.

Bowman, Herbert E. 1954. Vissarion Belinski, 1811-1848: A Study in the Origins of Social Criticism in Russia, Cambridge, MA: Harvard UP. Brodskii, N. L. 1910. Бродский, Н.Л. Рание славянофиль: А.С. Хомяков, И.В. Киреевский, К.С. и И.С. Аксаковы [The Early Slavophiles: A.S. Khomiakov, I.V. Kireevskii, K.S. i I.S. Aksakov]. Москва: Сыстин.

Brodskii, N. L. 1922. Бродский, Н.Л. И.С. Тургенев и русские сектанты [I.S. Turgenev and Russian Sectarians]. Москва: Издательство Литературного Кружка «Никитинские субботники».

Brodskii, N. L. (ed.) 2001. Бродский, Н.Л. (ред.). Литературные салоны и кружки: Первая половина ХІХ века [Literary Salons and Circles: The First Half of the Nineteenth Century]. Москва: Аграф (reprint of 1931 edition, Москва и Ленинград «Academia»).

Buganov, A. V. 2001. "Historical Views of the Russian Peasantry: National Consciousness in the Nineteenth Century," in Madhavan Palat, ed., Social Identities in Revolutionary Russia, NY: Palgrave, 65-85.

Chizhevskii, D. I. 1939. Чижевский, Д. И. Гегель в России [Hegel in Russia]. Париж: Дом книги и Современная записка.

Dal', V. I. 1880. Даль, В.И. О поверьях, суевериях, и предрассудах русского народа [About the Beliefs, Superstitions, and Prejudices of the Russian People]. Изд. Второе, Санкт Петербург и Москва: М.О. Вольф.

Dal', V. I. 1861. Даль, В.И. Пословицы русского народа [The Proverbs of the Russian People]. Москва.

Dal', V. I. 1863. Даль, В.И. Толковый словарь живого великорусского языка [Explanatory Dictionary of the Living Great Russian Language]. Москва: тип. А. Семена.

Danilov, Kirsha. 1958 [1804]. Данилов, Кирша. Древние российские стихотворения, собранные Киршею Даниловым [Ancient Russian Verses Collected by Kirsha Danilov], под ред. А.П. Евгеньевой и Б.Н. Путилова, Москва и Ленинград: АН СССР.

Edie, James, James Scanlan, and Mary-Barbara Zeldin, 1965. Russian Philosophy, 3 vols, Chicago: Quadrangle, vol. 1.

Field, Daniel. 1973. "Kavelin and Russian Liberalism," Slavic Review, vol. 32 , no. $1,59-78$. 
Gladkikh, Е. Р. 1996. Гладких, Е.П. «К.Д. Кавелин в истории фольклористики» [“K.D. Kavelin in the History of Folkloristics”]. Русский фольклор, т. 29, 86-97.

Gleason, Abbott. 1980. Young Russia: The Genesis of Russian Radicalism in the 1860s, New York: Viking.

Herzen, Alexander. 1968. My Past and Thoughts: Memoirs, 4 vols., tr. Constance Garnett, New York: Alfred Knoff, vol. 2.

Ivanits, Linda. 2008. "The Early Dostoevsky and Folklore: The Case of the Landlady," Slavic and East European Journal, vol. 52, no. 4, 513-28.

Jahn, Hubertus. 2004. “Us': Russians on Russianness," in Simon Franklin and Emma Widdis, eds., National Identity in Russian Culture: An Introduction, Cambridge: Cambridge University Press, 53-73.

Kamenskii, Z. A. 1988. Каменский, 3.А. Тимофей Николаевич Грановский [Timofei Nikolaevich Granovskii]. Москва: Мысль.

Kantor, V. K. and A. L. Ospovat. 1982. Кантор, В.К. и А.Л. Осповат, Русская эстетика и критика 40-50 годов XIX века [Russian Aesthetics and Criticism of the 1840s and 1850s]. Москва: Искусство.

Katkov, M. N. 1840. Катков, М.Н. «Михаил Максимович, История древней русской словесности (Киев, 1839)» [review of Mikhail Maksimovich, The History of Ancient Russian Literature]. Отечественные записки, 1840, т. 9, вып. 5, 37-68.

Katkov, M. N. 1839. Катков, М.Н. «Песни русского народа, изданные И. Сахаровым (Санкт Петербург, 1838-1839)» [review of I. Sakharov, Songs of the Russian People]. Отечественные записки, 1839, т. 4, вып. 6, 1-92.

Katz, Martin. 1966. Mikhail N. Katkov: A Political Biography, 18181887, The Hague and Paris: Mouton.

Kavelin, K. D. 1897. Кавелин, К.Д. Собрание сочинений [Collected Works], 4 тт., Санкт Петербург: Стасюлевич.

Khomiakov, А. S. 1852. Хомяков, А.С. «Предисловие» ["Foreword"]. Московский сборник, Москва: Семен, 319-331.

Kireevskii, P. V. 1845. Киреевский, П.В. «О древней русской истории (Письмо к М.П. Погодину)» [“'On Ancient Russian History (letter to M.P. Pogodin)"]. Москвитянин, 1845, № 3, вып. 3, 11-46.

Kireevskii, P. V. 1852. Киреевский, П.В. «Русские народные песни» и «Примечание» ["Russian Folk Songs" and "Remarks"]. Московский сборник, Москва: Семен, 333-66. 
Kireevskii, Р. V. 1860-1874. Киреевский, П.В. Песни, собранные П.В. Киреевским [Songs Collected by P.V. Kireevskii]. 10 тт., Под ред. П.А. Бессонова, Москва: Общество любителей Российской словесности (тип. Семена, Бахметева, и др.).

Kireevskii, P. V. 1935. Киреевский, П.В. Письма П.В. Киреевского к H.M. Языкову [Letters of P.V. Kireevskii to N.M. Iazykov]. Под ред. М.К. Азадовского, Москва и Ленинград: АН СССР.

Korsakov, D. 1896. Корсаков, Д. Константин Дмитриевич Кавелин:

Очерк жизни и деятельности [Konstantin Dmitrievich Kavelin: His Life and Work]. Санкт Петербург: тип. Главного Управления Уделов.

Leigton, Lauren Gray,(ed. and tr.), 1987. Russian Romantic Criticism: An Anthology, New York; Greenwood.

Lilly, Ian K. 1972. "N.M. Iazykov as a Slavophile Poet," Slavic Review, vol. 31, no. 4, 797-804.

McNally, Raymond T. 1964. "Chaadaev's Evaluation of Peter the Great," Slavic Review, vol. 23, no. 1, 31-44.

Maksimovich, Mikhail. 1827. Максимович, Михаил. Малороссийские песни [Little Russian Songs]. Москва: Семен.

Maksimovich, Mikhail. 1845. Максимович, Михаил. «О народной исторической поэзии в древней Руси (Письмо к М.П. Погодину» [“'On Historical Folk Poetry in Ancient Rus' (letter to M.P. Pogodin)"]. Москвитянин, 1845, № 3, вып. 3, 1-7.

Novikov, N.V 1959. Новиков, Н.В. «Г.И. Парихин и его фольклорные записи в сборнике И.П. Сахарова» [“G.I. Parikhin and his Folklore Transcriptions in the Collection of I.P. Sakharov"]. Русский фольклор, т. 4, 141-54.

Novikov, N.V (ed. and intro.) 1961. Новиков, Н.В. (ред.) Русские сказки в записях и публикачиях первой половинь XIX века [Russian Folktales in Transcriptions and Publications of the First Half of the Nineteenth Century]. Москва и Ленинград: АН СССР.

Novikov, N.V (ed. and intro.) 1971. Новиков, Н.В. (ред.) Русские сказки в записях и публикащиях (XVI-XVIII века) [Russian Folktales in Transcriptions and Publications (16 ${ }^{\text {th }}-18$ th centuries)]. Москва и Ленинград: Наука.

Offord, Derek. 1985. Portraits of early Russian liberals: A study of the thought of T.N. Granovsky, V.P. Botkin, P.V. Annenkov, A.V. Druzhinin and K.D. Kavelin, Cambridge: Cambridge University Press. 
Prilenskii, V. I. 1995. Приленский, В.И. Onыт исследования мировозрения раних русских либералов [An Attempt to Investigate the Worldview of Early Russian Liberals]. Москва: Российская А.Н.: Институт философии.

Pypin, A. N. 1891. Пыпин, А.Н. История русской этнографии [The History of Russian Ethnography]. Санкт Петербург: Стасюлевич, тт. 1 и 2.

Pypin, A. N. 1911. Пыпин, А.Н. История русской литературы [The History of Russian Literature]. Санкт Петербург: Стасюлевич, т. 3.

Riasanovsky, Nicholas V. 1965. Russian and the West in the Teaching of the Slavophiles: A Study of Romantic Ideology, Glouster, MA: Peter Smith.

Ryan, W. F. 2006. Russian Magic at the British Library: Books, Manuscripts, Scholars, Travellers, Panizzi Lectures for 2005, London: The British Library.

Sakharov, I. 1841. Сахаров, И. Сказания русского народа [Tales of the Russian People]. изд. третье, Санкт Петербург.

Sementkovskii, R. I. 1891. Сементковский, Р.И. М.Н. Катков: его жизнь и публицическая деятельность [M.N. Katkov: His Life and Activity as a Publisher]. Санкт Петербург: Общественная польза.

Shevyrev, Stepan. 1887. Шевырев, Степан. История русской словесности [History of Russian Literature]. изд. третье, Санкт Петербург: Имп. Академия наук.

Skaftymov, A. Р. 1936. Скафтымов, А.П. «Белинский и устное народное творчество» ["Belinskii and Oral Folk Art"]. Литературный критик, т. 7, 134-154.

Snegirev, I. 1837. Снегирев, И. Русские [Руские] простонародные праздники и суеверные обряды [Russian Celebrations and Superstitious Rituals of the Simple Folk]. 4тт., Москва: Университетская тип.

Soimonov, A. D. 1960. Соймонов, А.Д. «Записи былин первой половины XIX века в собрании П.В. Киреевского» ["Transcriptions of Byliny of the First Half of the Nineteenth Century in the Collection of P.V. Kireevskii"]. Русский фольклор, T. 5, 367-81.

Soimonov, A. D. 1968. Соймонов, А.Д. «П.В. Киреевский и русскославянские связи первой половины XIX в.» [“P.V. Kireevskii and Russian-Slavic Ties of the First Half of the Nineteenth Century"] 
Русский фольклор (Исторические связи в славянском фольклоре), т. 11, 240-258.

Soimonov, A. D. 1971. Соймонов, А.Д. П.В. Киреевский и его собрание народных песен [P.V. Kireevskii and his Collection of Folksongs]. Ленинград: Наука.

Sokolov, В.М. 1923. Соколов, Б.М. Собиратели народных песен: П.В. Киреевский, П.И. Якушкин, П.И. Штейн [Folksong Collectors: P.V. Kireevskii, P.I. Iakushkin, P.I. Shtein]. Москва: В.В. Думов.

Tereshchenko, A. 1848. Терещенко, А. Бызт русского народа [Daily Life of the Russian People]. Санкт Петербург: Тип. Мин-ства внут. Дел.

Terras, Victor. 1974. Belinskij and Russian Literary Criticism: The Heritage of Organic Aesthetics, Madison, WI: University of Wisconsin Press.

Thaden, Edward C. 1964. Conservative Nationalism in NineteenthCentury Russia, Seattle: University of Washington Press.

Thaden, Edward C. 1999. The Rise of Historicism in Russia, American University Studies, Series IX: History, vol. 192, New York: Peter Lang Press.

Tikhonova, Е. Iu. 1999. Тихонова, Е. Ю. В.Г. Белинский в споре со славянофилами [V.G. Belinskii in his Struggle with the Slavianophiles]. Москва: УРСС.

Turgenev, I. S. 1961. Тургенев, И.С. Полное собрание сочинений и писем [Complete Collection of Works and Letters]. Москва и Ленинград: АН СССР, Письма, т. 2.

Vlasova, Z. I. 1962. Власова, З.И. «Коллекция лирических песен в собрании П.В. Киреевского (30-е годы XIX в.)» [“The Collection of Lyric Songs in the Collection of P.V. Kireevskii (the 1830s)"]. Русский фольклор, т. 7, 328-342.

Vlasova, Z. I. 1976. Власова, 3.И. «В.И. Даль» [“V.I. Dal”"]. Русская литература и фольклор: Первая половина XIX века, под ред. А.А. Горелова, Ф. А. Приймы, и А.Д. Соймонова, Ленинград: Наука.

Walicki, Andrzej. 1975. The Slavophile Controversy: History of a Conservative Utopia in Nineteenth-Century Russian Thought, trans. Hilda Andrews-Rusiecka, Oxford: The Clarendon Press.

Wortman, Richard. 1962. "Koshelev, Samarin, and Cherkassky and the Fate of Liberal Slavophilism," Slavic Review, vol. 21, no. 2, pp. 261-279. 
Zemlianova, L. М. 1958. Землянова, Л.М. «О роли фольклора в литературной деятельности П.И. Якушкина» [“On the Role of Folklore in the Literary Activity of P.I. Iakushkin"]. Русский фольклор (Материаль и исследования), т. 3, 184-202. 